\title{
Penerimaan Pesan Persuasif dari Perspektif Elaboration Likelihood Model : Iklan Layanan Masyarakat Himbauan Berhenti Merokok
}

\author{
Chairun Nisa Dwi Putri ${ }^{1}$, Alvin Gus Abdurrahman Wahid ${ }^{2}$, Irwansyah ${ }^{3}$ \\ ${ }^{1,2,3}$ Program Studi Ilmu Komunikasi, Fakultas Ilmu Sosial Ilmu Politik, Universitas Indonesia \\ Jl. Salemba Raya No 4, 10430, Jakarta Pusat, DKI Jakarta, 10440, Indonesia \\ Email: ${ }^{1}$ chairun.nisa01@ui.ac.id, ${ }^{2}$ alvin.gus01@ui.ac.id, ${ }^{3}$ irwansyah09@ui.ac.id
}

Received: June 2021; Accepted: October 2021; Published: December 2021

\begin{abstract}
The number of smokers among Indonesian teenagers continues to increase every year. Public service advertisements (PSA) for smoking prevention must be delivered with the right approach to be accepted in the minds of the audience. This study aims to expand on previous research on smoking prevention PSAs by testing the concept of the Elaboration Likelihood Model theory. The research method applied is exploratory qualitative which is complemented by the results of in-depth interviews with 4 participants of postgraduate students of communication science at the University of Indonesia. The results of this study indicate that attitudes towards issues and personal relevance are the factors that most influence the acceptance of persuasive messages on PSAs that prohibit smoking \#SuaraTanpaRokok. Repetition can be used to increase the effectiveness of a given persuasive message.
\end{abstract}

Keywords: Elaboration Likelihood Model, Smokin Prevention, Public Service Advertisement

\begin{abstract}
Abstrak
Jumlah perokok di kalangan remaja Indonesia terus meningkat setiap tahun. Iklan layanan masyarakat (ILM) untuk pencegahan merokok harus disampaikan dengan pendekatan yang tepat agar dapat diterima di benak audiens. Penelitian ini bertujuan untuk memperluas penelitian terdahulu mengenai ILM pencegahan merokok dengan menguji konsep pada teori Elaboration Likelihood Model. Metode penelitian yang diterapkan adalah kualitatif eksploratif yang dilengkapi hasil wawancara mendalam kepada 4 partisipan mahasiswa pasca sarjana ilmu komunikasi universitas indonesia. Hasil penelitian ini menunjukan bahwa sikap terhadap isu dan relevansi personal adalah faktor yang paling mempengaruhi penerimaan pesan persuasif pada ILM pencegahan merokok \#SuaraTanpaRokok. Repetisi dapat digunakan untuk meningkatkan keefektifan pesan persuasif yang diberikan.
\end{abstract}

Kata Kunci: Model Kemungkinan Elaborasi, Pencegahan Rokok, Iklan Layanan Masyarakat

\section{PENDAHULUAN}

Saat ini kita dapat menjumpai iklan rokok dimana saja, tidak hanya di televisi. Sudah menjadi pengetahuan umum yang ada di masyarakat bahwa rokok sangat membahayakan kesehatan perokok dan juga perokok pasif di sekitarnya, namun laporan dari Tobacco Control Support Centre - Ikatan Ahli Kesehatan Masyarakat Indonesia pada tahun 2018 menyebut bahwa Indonesia adalah satu satunya negara di Asia Tenggara yang tidak memiliki aturan larangan iklan rokok, sehingga sampai sekarang kita masih akan terus menemuinya. Ditambah lagi, usia perokok kini semakin muda (Suatan \& Irwansyah, 2021)

doi: https://doi.org/10.51544/jlmk.v5i2.1673

(C) 2021 Jurnal Lensa Mutiara Komunikasi. This is an open access article under the CC BY-SA license Website: http://e-journal.sari-mutiara.ac.id/index.php/JLMI

http://e-journal.sari-mutiara.ac.id 
Rita Pranawati selaku Wakil Ketua Komisi Perlindungan Anak Indonesia (KPAI) dalam wawancaranya dengan media online Kompas pada 2019 lalu menilai bahwa iklan rokok di internet bisa jauh lebih parah dampaknya bagi anak-anak dibandingkan dengan di televisi yang dibatasi waktunya. Berbagai upaya sudah dilakukan oleh pemerintah agar dapat mengurangi jumlah perokok aktif saat ini. Namun hal tersebut tidak memberikan dampak yang signifikan. Berbagai iklan layanan masyarakat mengenai bahaya merokok kalah dengan iklan-iklan rokok yang ada di televisi atau bahkan di internet saat ini. Staf Khusus Menteri Kesehatan, Alexander K. Ginting pada wawancaranya dengan portal berita online HarianJogja.com bulan Juli 2020 lalu telah mengakui dibandingkan dengan kampanye kesehatan, iklan rokok baik tembakau maupun elektrik jauh lebih menggema di masyarakat.

Signifikansi artikel ini hadir dengan mengeksplorasi bagaimana iklan layanan masyarakat kampanye anti rokok dapat diterima oleh masyarakat, sehingga diharapkan dapat memiliki signifikansi praktis untuk pembuatan kampanye anti rokok yang lebih baik ke depannya.

Pemerintah memutuskan untuk bekerja sama dengan salah satu organisasi kesehatan yaitu Vital Strategies untuk mempromosikan kampanye sosial anti merokok dengan tagar \#SuaraTanpaRokok. Salah satu strategi yang digunakan adalah dengan membuat iklan layanan masyarakat pada kanal youtube Vital Strategies Indonesia dan akun twitter @ suaratanparokok. Video yang dibuat pada sosial media tersebut menggunakan pendekatan yang berbeda-beda untuk mencapai target audience. Sesuai dengan teori Elaboration Likelihood Model (ELM) oleh (Petty \& Cacioppo, 1986) yang menekankan pada pentingnya memahami karakteristik komunikan sebelum memberikan persuasi. Teori ini membagi jalur penerimaan pesan menjadi dua bagian yaitu central routes (rute pusat) dan peripheral routes (rute perifer). Pemikiran kritis individual terjadi di rute pusat, sedangkan pemikiran sederhana yang dipengaruhi faktor situasional terjadi di rute perifer.

Iklan layanan masyarakat (ILM) bertujuan untuk mempersuasi seseorang agar bersikap dan berperilaku sesuai dengan yang diharapkan. Penelitian terhadap ILM sebelumnya sudah dilakukan oleh (Citrasiwi, 2015) dengan judul Pembentukan Sikap Masyarakat Terhadap Kesehatan Diri Melalui Kampanye 10 Perilaku Hidup Bersih dan Sehat. Hasil penelitian ini menunjukkan bahwa ada hubungan yang kuat antara kampanye tersebut dengan sikap masyarakat terhadap kesehatan diri. Pesan yang dibuat serta pengirim pesan kampanye dapat mempengaruhi pemahaman, perasaan, dan perubahan perilaku masyarakat terhadap kesehatan diri. Meski demikian, penelitian ini tidak mengkaji lebih dalam seluruh konsep yang ada pada teori elaboration likelihood model. Penelitian ini 
fokus pada konsep argumentasi pesan pada rute pusat dan kredibilitas pengirim pesan pada pusat perifer saja. Variabel motivasi dan kemampuan pada rute pusat seperti relevansi personal, keinginan untuk memproses pesan, distraksi saat memproses pesan, pengetahuan terhadap isu sebelumnya, dan sikap sebelum menerima pesan tidak dikaji. Pada rute perifer, peneliti juga tidak menganalisis konsep pengaruh pandangan orang lain dan keinginan untuk memperoleh penghargaan dari luar.

Data dari situs world population review 2020 menunjukan bahwa Indonesia menempati posisi ke 7 sebagai negara dengan jumlah perokok terbanyak di dunia. Jumlah ini jauh lebih banyak jika dibandingkan dengan negara Taiwan. (Huang et. al, 2016) melakukan penelitian untuk melihat ILM mana yang paling efektif untuk mencegah peningkatan pengguna rokok di Taiwan. Penelitian dengan judul Which Types of AntiSmoking Television on Advertisement Work Better in Taiwan? ini membandingkan 8 ILM larangan merokok dan menemukan bahwa iklan Oral Cancer berfungsi paling efektif untuk membuat orang berhenti merokok. Berisikan testimoni dari pengidap kanker mulut, iklan ini membangun aspek emosional, pemahaman, kredibilitas dan relevansi yang baik dengan penggabungan isyarat yang ada di rute pusat dan perifer. Efektifitas iklan sangat lah berpengaruh dalam keputusan penontonnya (Briandana et. Al, 2020). Sesuai dengan rekomendasi dari (Bator dan Cialdini, 2000) untuk menggabungkan isyarat pusat dan periferal untuk meningkatkan penerimaan pesan. Penelitian ini mengkaji konsep relevansi personal dan pengetahuan terhadap isu sebelumnya pada rute pusat, serta aspek emosional pada rute perifer. Tetapi peneliti belum mengkaji konsep keinginan untuk memproses pesan, distraksi dari luar dan sikap terhadap isu sebelumnya pada rute pusat. Kemudian pada rute perifer, peneliti tidak mengkaji konsep kredibilitas pengirim pesan, tanggapan orang lain dan keinginan untuk memperoleh penghargaan dari luar.

Penelitian sebelumnya yang berjudul Effects of Anti-Smoking Public Service Announcements on the Attitudes of Korean College Students toward Smoking yang dipublikasikan pada tahun 2017 dan dilakukan oleh Co et al memberikan hasil bahwa untuk pesan positif, proporsi perubahan keyakinan dan sikap masing-masing adalah $39,1 \%$ dan $19,8 \%$, sedangkan yang memiliki pesan negatif menunjukkan proporsi perubahan kepercayaan dan sikap yang lebih besar $(59,7 \%)$ dan sikap (40,3\%). Setelah dilakukan penyesuaian jenis kelamin dan perubahan keyakinan, jenis pesan dan status merokok diidentifikasi sebagai faktor yang mempengaruhi perubahan sikap peserta. Pesan negatif menghasilkan perubahan yang lebih besar dalam sikap. Perokok pernah termasuk perokok aktif menunjukkan perubahan sikap positif yang lebih besar daripada yang tidak pernah 
merokok (Cho et al., 2017). Penelitian ini menemukan bahwa iklan layanan publik anti rokok yang positif lebih efektif pada perubahan sikap daripada pesan negatif. Selain itu, iklan ini lebih efektif di antara audiens yang merupakan perokok aktif atau memiliki pengalaman merokok sebelumnya.

Penelitian terkait penerapan teori Elaboration Likelihood Model di sosial media sudah pernah dilakukan sebelumnya, (Khong dan Teng, 2015) dalam penelitiannya Conceptualising Cues in Social Media melakukan systematic review terhadap 143 artikel jurnal terkait, sebagian besar atau 123 jurnal yang ditemukan fokus pada isyarat di rute perifer, hanya 19 jurnal yang meneliti isyarat pada rute pusat. Namun konsep dari rute pusat yang diteliti pada penelitian ini hanya konsep kualitas argumen saja, konsep relevansi personal, keinginan untuk memproses pesan, distraksi dari luar, pengetahuan terhadap isu sebelumnya dan sikap terhadap isu tersebut tidak ikut diteliti. Sedangkan pada rute perifer konsep yang diteliti hanya kredibilitas pengirim pesan saja, konsep tanggapan dari orang lain dan keinginan untuk memperoleh penghargaan tidak ikut diteliti. ELM memberikan prediksi yang sangat jelas ketika audiens memiliki motivasi dan kemampuan untuk mengelaborasi pesan maka komunikator harus memberikan argumen yang kuat dan faktual. Sebaliknya, komunikator harus fokus untuk membangun emosi ketika audiens tidak bisa mengelaborasi pesan. Jika audiens berhasil memproses informasi melalui rute pusat, hasilnya cenderung bertahan lama. Sedangkan pada rute perifer, selain tidak bertahan lama, efeknya juga akan terlihat minim.

Saat ini internet dan sosial media hadir dan memberikan kita kemudahan akses untuk memperoleh informasi. Selain berfungsi untuk menghibur, Youtube bisa digunakan oleh organisasi maupun individu untuk mengedukasi khalayak. Berbagai kampanye global bahkan menggunakan Youtube sebagai medianya karena dinilai memiliki kemampuan untuk menjangkau audiens yang sangat luas (Sugianto, 2019).

Berdasarkan latar belakang yang sudah disampaikan diatas. Tujuan penelitian ini dilakukan adalah untuk menganalisis efektivitas penerimaan pesan persuasif ajakan berhenti merokok pada kanal youtube Vital Strategies Indonesia dan akun twitter @ suaratanparokok dengan melengkapi konsep dari teori Elaboration Likelihood Model yang belum dikaji dari beberapa penelitian sebelumnya. 


\section{TINJAUAN LITERATUR}

Penelitian terhadap sikap dan persuasi dimulai sebagai fokus utama pada bidang psikologi sosial di tahun 1908-1930. Namun setelah cukup berkembang, di tahun 19301960 minat terhadap topik ini mulai berkurang. Terdapat dua faktor yang mempengaruhi hal ini: Pertama, peneliti bertanya-tanya apakah sikap mampu memprediksi perilaku. Kedua, banyak teori yang yang saling bertentangan tentang bagaimana mengubah sikap seseorang. Pada akhir tahun 1970 para peneliti mulai menyelidiki konsistensi antara sikap dan perilaku serta kondisi di mana sikap dapat dan tidak dapat memprediksi perilaku. Terdapat kesepakatan bahwa pengirim, pesan, penerima dan saluran yang digunakan, dapat mempengaruhi perubahan sikap seseorang. Pada tahun 1986 muncul teori Elaboration Likelihood Model yang membantu kita untuk memahami proses dasar yang mendasari efektivitas komunikasi persuasif untuk mengubah sikap dan perilaku seseorang dengan membagi proses pengelolaan informasi melalui central route dan peripheral route (Petty \& Cacioppo, 1986). Teori ELM dikembangkan oleh psikolog sosial Richard Petty dan John Cacioppo, teori ini fokus pada bagaimana komunikator melakukan persuasif (Petty \& Cacioppo, 1986) . Di satu sisi, persuasi dilihat sebagai proses kognitif yang dilakukan audiens untuk menerima atau menolak pesan yang disampaikan.

ELM dimulai dengan premis bahwa manusia terkadang mengevaluasi pesan dengan cara yang rumit, menggunakan pemikiran kritis, dan terkadang dilakukan dengan cara yang lebih sederhana dan tidak kritis. Pada ELM, terdapat dua rute saat seseorang memproses informasi yaitu central route dan peripheral route (Littlejohn, 2016). Berikut adalah rangkuman kedua rute sebagai berikut:

\section{Central Route (Rute Pusat)}

Saat individu memproses informasi melalui rute pusat, maka ia akan membandingkan keabsahan pesan yang baru diterimanya dengan pengetahuan yang sudah dimiliki sebelumnya. Argumen akan menjadi faktor penting untuk dipertimbangkan. Perubahan sikap komunikan setelah memproses pesan yang diberikan pada rute ini biasanya bertahan lama dan akan mempengaruhi perilakunya. Orang tersebut akan memproses pesan melalui rute pusat ketika topik yang dibahas berkaitan dengan dirinya, kemudian orang tersebut sudah memahami topik yang disampaikan. (Littlejohn, et. al., 2012). 


\section{Peripheral Route (Rute Perifer)}

Proses informasi yang dilakukan pada rute perifer tidak melibatkan pemikiran kritis, individu tidak melihat dari dekat kekuatan dari argumen yang diberikan dan membuat membuat penilaian dengan cepat berdasarkan isyarat sederhana. Faktor seperti ketertarikan dan kredibilitas komunikator, apakah ada konsensus di antara mereka yang mendengarkan pesan tersebut serta suasana hati pada saat itu menjadi kemungkinan yang dipertimbangkan saat memilih rute perifer. Ketika audiens tidak memiliki motivasi dan kemampuan untuk memproses informasi maka komunikator dapat mempertimbangkan cara cepat untuk mengubah sikap persuasi melalui cara rute perifer meskipun perubahan sikap yang dihasilkan tidak bertahan lama.

Pesan di rute perifer menekankan pada keterlibatan emosional audiens. Cialdini (dalam Dainton, 2018) mengidentifikasi tujuh isyarat pada pesan perifer yaitu: Authority, Commitment, Contrast, Liking, Reciprocity, Scarcity and Social Proof. Otoritas dapat digunakan untuk mempengaruhi perilaku seseorang, misalnya ketika orang tua menyuruh anaknya. Bentuk komitmen bisa dilihat dari simbol yang sering digunakan seseorang untuk menunjukkan organisasinya misalnya pita merah pada organisasi pencegahan HIV/AIDS. Kontras biasanya digunakan oleh penjual kepada pembeli dengan menunjukkan barang yang paling mahal terlebih dahulu baru menunjukkan barang yang paling murah. Ketertarikan biasanya dilakukan dengan memilih tokoh terkenal sebagai brand ambassador suatu produk. Timbal balik biasanya digunakan ketika seseorang meminta tolong kepada keluarganya yang sudah banyak membantu dirinya. Kelangkaan ditunjukkan dengan memberikan urgensi kepada audiens untuk segera bertindak dengan cepat misalnya ketika menawarkan barang diskon dalam periode waktu yang terbatas. Bukti sosial bisa dilihat saat saat seseorang mendonorkan darah agar dianggap bijaksana oleh orang lain. Rute ini juga menghasilkan perubahan sikap yang kuat, netral dan lemah meskipun tidak bertahan lama.

\section{METODE PENELITIAN}

Beberapa langkah-langkah untuk melakukan penelitian ini adalah sebagai berikut: 1) Menentukan jenis penelitian, 2) Menentukan objek penelitian, 3) Menentukan data dan sumber data, 4) Menentukan teknik data pengumpulan, dan terakhir 5) Menentukan teknik analisis data. Penelitian ini menggunakan pendekatan kualitatif. Objek dalam penelitian ini adalah iklan layanan masyarakat mengenai bahaya merokok pada kanal youtube Vital Strategies Indonesia. Ada dua jenis sumber data yang digunakan dalam penelitian ini yaitu sumber data primer dan sumber data sekunder: a. Sumber data primer penelitian ini adalah 
hasil wawancara mendalam terhadap 4 narasumber mahasiswa pascasarjana ilmu komunikasi indonesia angkatan 2020-2022 b. Data sekunder berasal dari sumber lain yang terkait dengan studi tersebut, seperti; website, kamus, jurnal, buku dan lain sebagainya yang mendukung analisis. Beberapa langkah pengumpulan data yang dilakukan yaitu: Melakukan wawancara mendalam dan Mengumpulkan beberapa data pendukung dari referensi lain yang berkaitan dengan topik. Oleh karena itu, permasalahan yang muncul akan dapat terjawab dengan tuntas untuk menarik kesimpulan dari analisis yang telah dilakukan sebelumnya. Teknik analisis data dilakukan dengan menentukan instrumen penelitian, yaitu peneliti itu sendiri. Adapun alasannya sesuai yang dikemukakan oleh Lincoln dan Guba (1985 hlm. 39) bahwa semua instrumen dapat berinteraksi dengan responden dan objek penelitian namun tetap saja hanya instrumen manusia yang mampu menangkap dan mengevaluasi arti dari interaksi diferensial (Lincoln \& Guba, 1985).

Populasi pada penelitian ini adalah seluruh Mahasiswa/i Pascasarjana Ilmu Komunikasi Universitas Indonesia angkatan 2020-2022. Sampel pada penelitian ini ditentukan berdasarkan metode snowball sampling dimana peserta penelitian merekrut peserta lain untuk mengikuti suatu tes atau studi. Secara etis, peserta studi tidak boleh diminta untuk mengidentifikasi peserta potensial lainnya. Sebaliknya, mereka harus diminta untuk mendorong orang lain untuk ikut serta pada penelitian yang dilakukan. Pengambilan sampel bola salju adalah metode pengambilan sampel non-probabilitas atau pengambilan sampel acak sederhana (di mana peluangnya sama untuk peserta tertentu yang dipilih). Sebaiknya, para peneliti menggunakan penilaian mereka sendiri untuk memilih peserta. Penentuan tersebut harus mewakili prasyarat penelitian yaitu seorang perokok aktif, bukan perokok namun tinggal di lingkungan yang merokok, dan tidak pernah merokok sama sekali.

Objek penelitian ini adalah video iklan layanan masyarakat di kanal youtube Vital Strategies Indonesia dan akun twitter @SuaraTanpaRokok dengan tagar \#SuaraTanpaRokok. Terdapat 2 versi iklan yang diteliti pada penelitian ini yang dijelaskan pada Tabel 1. 
Tabel 1.

Objek Penelitian

\begin{tabular}{|c|c|c|}
\hline $\begin{array}{l}\text { Nama } \\
\text { Iklan }\end{array}$ & Sumber & Deskripsi Iklan \\
\hline $\begin{array}{l}\text { Penyakit } \\
\text { yang } \\
\text { diakibatkan } \\
\text { rokok }\end{array}$ & 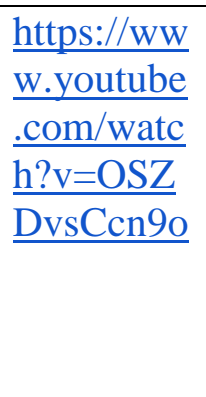 & $\begin{array}{l}\text { Video ini menampilkan seseorang yang sedang ragu-ragu untuk } \\
\text { merokok karena memikirkan penyakit yang akan menimpa } \\
\text { dirinya dan membuatnya menjadi beban keluarga jika terus } \\
\text { merokok. Kemudian ditampilkan beberapa video asli dari orang } \\
\text { yang terkena penyakit stroke, kanker tenggorokan, kanker paru- } \\
\text { paru dan penyakit buerger. Di akhir video muncul teks "Penyakit } \\
\text { apa yang akan menimpamu jika merokok?" dan "Berhentilah } \\
\text { merokok sekarang juga". }\end{array}$ \\
\hline $\begin{array}{l}\text { \#SuaraTanp } \\
\text { aRokok }\end{array}$ & $\begin{array}{l}\frac{\text { https://twit }}{\text { ter.com/Su }} \\
\frac{\text { araTanpaR }}{\text { okok/statu }} \\
\frac{\text { s/1346392 }}{46281060} \\
\underline{7616 ? \mathrm{~s}=20}\end{array}$ & $\begin{array}{l}\text { Video ini menampilkan testimoni dari seorang perempuan } \\
\text { bernama Wiwi yang berusia } 61 \text { tahun dan menderita penyakit } \\
\text { jantung koroner dengan } 11 \text { penyumbatan. Kilas balik saat dirinya } \\
\text { sedang berada di rumah sakit bersama keluarga ditampilkan } \\
\text { dalam bentuk foto-foto dengan backsound suara dirinya } \\
\text { menceritakan momen ketika terkena serangan jantung dan operasi } \\
\text { bypass. Pada akhir video wiwi memberikan pernyataan "Stop } \\
\text { smoking, your life would be better". }\end{array}$ \\
\hline
\end{tabular}

Konsep dari teori ELM yang dikaji pada penelitian ini meliputi seluruh isyarat pada rute pusat dan rute perifer. Pada rute pusat, konsep relevansi personal, keinginan untuk memproses pesan, distraksi dari luar, pengetahuan terhadap isu sebelumnya, kualitas argumen, dan sikap sebelum memperoleh pesan persuasi dianalisis oleh peneliti. Kemudian pada rute perifer, konsep kredibilitas pengirim pesan, tanggapan orang lain dan keinginan untuk memperoleh penghargaan juga ikut diteliti.

\section{HASIL DAN PEMBAHASAN}

Penelitian mengenai efektivitas pesan persuasif di sosial media menggunakan teori ELM sudah banyak dilakukan, hal tersebut dijelaskan dalam penelitian Teng et al. yang berjudul Conceptualizing Persuasive Messages Using ELM in Social Media (2014) dengan metode penelitian systematic review. Teng pada penelitiannya berhasil menemukan 23 jurnal terkait pengaplikasian teori ELM di sosial media yang telah dikumpulkan dari tahun 2006-2014. Negara asia paling banyak melakukan penelitian ini, dengan jumlah sebesar $23 \%$ dari total keseluruhan artikel jurnal sudah diterbitkan oleh peneliti asal Taiwan. Sebagian besar artikel membahas tentang pengguna media sosial dalam memproses iklan di web dengan metode penelitian eksperimen. Penelitian ini menjadi suatu kebaruan dengan fokus penelitian pesan iklan layanan masyarakat dari kanal youtube Vital Strategies 
Indonesia dengan menggunakan metode penelitian kualitatif analisis isi dan wawancara mendalam.

Flynn et al. dalam penelitiannya yang berjudul Evaluation of Smoking Prevention Television Messages Based on The Elaboration Likelihood Model (2011) berusaha untuk menganalisis pengaruh pesan yang menekankan argumen faktual tentang dampak negatif dari merokok secara eksplisit dibandingkan dengan pesan yang memberikan argumen secara implisit dan hanya fokus pada norma sosial mengenai perokok di mata masyarakat. Flynn juga mengkategorikan siswa yang tidak merokok namun tinggal di lingkungan yang merokok sebagai kelompok yang memiliki motivasi tinggi untuk memproses pesan dibandingkan dengan siswa yang tinggal di lingkungan yang bebas rokok. Kemampuan untuk memproses pesan dilihat berdasarkan nilai yang diperoleh siswa selama bersekolah, siswa yang mempunyai nilai A/B dianggap memiliki kemampuan yang cukup baik untuk memproses pesan secara kognitif sedangkan siswa yang mempunyai nilai $\mathrm{C} / \mathrm{D}$ dianggap memiliki kemampuan yang kurang baik untuk memproses pesan secara kognitif (Flynn et al., 2011).

Meski peneliti menggali lebih dalam mengenai perbandingan gender dan ras partisipan, namun belum mencakup seluruh konsep yang ada pada teori ELM. Penelitian ini tidak meneliti lebih lanjut faktor yang ada di jalur pusat seperti pengaruh distraksi dari luar dan pandangan audiens dalam melihat isu sebelum menerima pesan persuasif. Pada jalur perifer, peneliti juga tidak memperhatikan faktor kredibilitas pemberi pesan, anggapan orang lain terhadap pesan persuasi yang disajikan dan penghargaan dari eksternal untuk menerima pesan persuasi.

Pesan dengan desain grafis menarik dapat mempersuasi audiens yang memiliki kemampuan elaborasi rendah secara efektif. Sejalan dengan penelitian Nkunya et al., (2017) yang berjudul Enhancing The Effectiveness Of Tobacco Package Warning Labels: An Elaboration Likelihood Perspective (2017) saat meneliti pesan kesehatan dan bahaya merokok pada bungkus rokok yang didesain menarik. Partisipan penelitian ini adalah 60 orang perokok aktif (merokok 10 batang dalam sehari) yang merupakan mahasiswa perguruan swasta di Selangor, malaysia. Pemerintah Malaysia menerapkan kebijakan pada perusahaan industri rokok untuk menampilkan gambar bahaya dari merokok dan teks dengan penjelasan singkat pada bungkus rokok yang dijual. Pesan persuasif dengan desain menarik dinilai efektif meskipun tidak menghasilkan perubahan sikap yang signifikan pada responden penelitian untuk berhenti merokok. Penelitian ini cukup lengkap membahas faktor-faktor yang ada di rute pusat dari teori ELM, namun penelitian ini belum membahas pengaruh distraksi dari luar saat responden memproses pesan. Selain itu, faktor-faktor yang 
ada di rute perifer seperti kredibilitas pemberi pesan, reaksi sekitar terhadap pesan persuasi yang diterima dan keinginan untuk mendapatkan penghargaan dari luar ketika memproses pesan persuasi.

Hasil dari penelitian ini memperlihatkan adanya perbedaan dengan penelitian sebelumnya. Penelitian sebelumnya mengaggap ILM cukup informatif tetapi tidak detil. Hal menarik yang ditemui pada penelitian ini adalah ILM mengenai kampanye untuk tidak merokok yang tersampaikan sudah memberikan informasi yang jelas. Meskipun Narasumber menyampaikan bahwa ILM menarik perhatiannya, namun di dalam penelitian ini 4 Narasumber menyampaikan bahwa sikap menerima atau tidaklah yang menentukan diterima nya informasi yang disampaikan oleh ILM. Dalam Penelitian ini, terdapat beberapa temuan menarik dan belum ada pada penelitian sebelumnya.

Sulit untuk mengubah opini masyarakat melalui ILM meskipun penyampaiannya sudah baik dan jelas menunjukkan bahwa merokok tidak baik bagi kesehatan diri dan orang sekitar.

Rachdian (Narasumber 3): "Ya.. kalo dari segi psikologis kan kita ada yang dari diri kita ada yang dari luar kita gitu ya.. Kalo dari kita atau misalkan kita bergerak karena lingkungan kita.. Nah kembali ke awal kalo belum menyerempet ke kepentingan kita sendiri biasanya orang ga akan berhenti gitu kan ya atau ga merasa terpengaruh lah kasarnya gitu.. Kalo ya jangan sampe sih punya penyakit dulu baru berhenti atau sejenisnya.. Tapi memang harusnya berhenti sih tapi tidak semudah itu soalnya gitu.. Tidak semudah itu..”

Pandangan di atas sulit diubah karena rokok sudah menjadi kebiasaan atau habit yang tidak dapat terhindarkan khususnya di Indonesia, karena di Indonesia rokok tidak hanya dijual per bungkus, dapat juga dijual per-batang. Hal ini membuat rokok dapat dijangkau oleh semua kalangan, yang bahkan anak SMP pun merokok dengan menyisihkan uang jajannya. Merokok bukanlah hal yang bisa disebut "mahal".

Abed (Narasumber 1) : "Perokok itu akan bertambah udah.. Kenapa.. Karena di Indonesia udah rokok di ketengan. Rokok semata... bayangin kalo.. Kalo di Indonesia itu rokok dijual perbungkus ga dijual per batang.. Nah kemungkinan potensi orang yang merokok itu berkurang” 
Bahkan Narasumber 4 (Faza) menyampaikan dalam wawancara bahwa ia mulai mengenal rokok saat kelas $2 \mathrm{SD}$.

Faza (Narasumber 4) : "Mulai merokok itu penasaran itu kelas 2 SD. Iya SD.. itu persoalan ini sih ngeliat apa lingkungan supir ya kan ngerokok nah penasaran masih bocah kan.".

Temuan menarik lainnya dalam Penelitian ini, Iklan Layanan Masyarakat dapat mengubah strategi nya dengan menyampaikan pesan bukan dari perspektif kesehatan, namun dapat pula dari perspektif ekonomi masyarakat. Misalkan berhenti merokok dapat lebih menghemat keuangan. Bentuk pesan atau narasi yang ada di dalam iklan tersebut akan berpengaruh apabila berkaitan dengan kepentingan individu penerima pesan.

Rachdian (Narasumber 3): “yang bagus tuh kaya gimana ya.. Kalo di kalo bagi saya sih yang.. yang ngaruh ya.. Yang bener-bener menyerempet kepentingan per individu nya.. Gitu jadi itu sih sebenernya definisi iklan yang bagus secara umum ya menyerempet kepentingan individu nya.. Gitu jadi.. Mungkin kalo ke yang mahasiswa belom mikirin duit mungkin bisa impoten kalo ngerokok.. Ga bisa punya anak dan lain-lain. Terus kalo udah punya keluarga paling ekonomi gitu.."

Pada Penelitian sebelumnya, pesan negatif menghasilkan perubahan yang lebih besar dalam sikap. Perokok pernah termasuk perokok aktif menunjukkan perubahan sikap positif yang lebih besar daripada yang tidak pernah merokok. Namun, di dalam penelitian ini pesan negative yang disampaikan melalui Iklan Layanan Masyarakat tidak berpengaruh besar kepada sikap untuk berhenti merokok meskipun pesan pada iklan sudah dibuat sedemikian rupa.

Faza (Narasumber 4) : “iya secara informasi jelas, tujuannya jelas untuk berhenti merokok, videonya bagus tapi pesannya kalo buat saya kurang menarik..

Bentuk pesan atau narasi yang ada pada iklan sudah bersifat mengajak atau persuasi untuk berhenti merokok atau tidak merokok. Seperti yang disampaikan oleh Narasumber 2:

Heru (Narasumber 2): "Sebenernya kalo layanan masyarakat umumnya sih udah bagus ya..

Udah dikasih gambar serem, udah di kasih apa namanya..istilahnya peringatan lu entar kalo begini sakit jantung.. Nah itu udah.. Udah..udah bener istilahnya uda mengajak.."

Pada dasarnya, motivasi dalam diri (termasuk ke dalam central route) 4 informan pada penelitian ini lebih kuat dibandingkan dengan pesan pada iklan yang disampaikan, yang bisa dipengaruhi oleh peripheral route. 
Abed (Narasumber 1) : "Kalo sumber perusahaannya sih kalo menurut saya apa ya hmm.. Walaupun ada yang.. Ada yang kanker paru-paru ada yang begini ada yang kena begini.. Itu belum efek loh ke masyarakat".

Faza (Narasumber 4) : "Kalo untuk berhenti menurut saya itu ga ngaruh.. dari yang dari

Youtube dari Twitter dan lain sebagainya itu ga begitu ngaruh..

Yang penting kita sebagai pe.. Nontonin iklan layanan masyarakat itu bisa dapet pesannya.. Kecuali kalo yang tadi yang kata mas Alvin pengen berhenti merokok kalo yang ngomong orang rokok boleh ga percaya”

Penelitian terhadap pengaruh kredibilitas sumber dalam pesan persuasif pada perilaku kesehatan terutama bertujuan untuk berhipotesis bahwa sumber yang sangat kredibel harus menghasilkan sikap yang lebih positif terhadap pesan iklan. Kredibilitas pembuat pesan iklan Layanan Masyarakat tentang rokok, menurut Narasumber 3 adalah penting. Misal yang menjadi creator nya adalah suatu Lembaga di Negara. Sesuai yang disampaikan oleh Narasumber 3 (Rachdian) dalam hasil wawancara di bawah ini:

Rachdian (Narasumber 3) : "Secara teori harusnya berpengaruh ya.. Secara teori harusnya berpengaruh kalo untuk orang-orang.. Kalo untuk saya sendiri sih berpengaruh karena apa namanya.. Hmm lembaga yang berkaitan ngomong kayak misalkan kementerian kelautan atau apapun.."

Namun, hasil pada penelitian ini, kredibilitas pembuat pesan iklan tidak terlalu mempengaruhi persepsi Narasumber untuk berhenti merokok atau menjauhi rokok. Narasumber 2 (Heru) mengatakan bahwa kredibilitas pembuat iklan tidak berpengaruh karena merupakan hal yang tergantung kepada penilaian sosial, apakah hal tersebut adalah penting atau tidak. Narasumber 2 tidak berpendapat sebagai pribadi diri sendiri, namun memposisikan diri sebagai anggota masyarakat yang netral terhadap rokok meskipun Narasumber bukanlah perokok.

Heru (Narasumber 2) : "Saya kira kalo kaya gitu tergantung penilaian social. itu karena gimana ya kalo misalkan kita melihat siapa yang menyampaikan itu pasti .. itu pasti.. Kemenkes memang kewenangan dia menyampaikan hal-hal yang bisa menunjang kesehatan di masyarakat atau dari NGO yang anti rokok itu memberikan penyuluhan itu bagus sekali tapi yang penting adalah lingkungan.. Lingkungan bagaimana lingkungan itu memperlakukan si perokok.

Dikarenakan Narasumber 2 sendiri bukanlah perokok aktif. Narasumber 2 lebih memperhatikan lingkungan atau orang lain supaya tidak terkena asap rokok dan sakit. Narasumber 2 tidak melakukan apa yang ada di dalam pesan iklan tersebut dengan tujuan 
untuk memperoleh penghargaan dari lingkungan sekitar. Seperti pendapat yang disampaikan oleh Narasumber 2 dalam wawancara :

Heru (Narasumber 2) : "Potensi bahayanya khawatir lebih tinggi daripada rokok asli itu..

Makanya kadang kalo memang tidak mengenakan untuk kita mendingan kita yang pindah.. Daripada ntar sakit dua-duanya dia yang ngerokok lu yang sakit, lebih parah sakitnya ntar, paling ga kita udah ngingetin nih bahaya ini loh.. Itu berhenti sih ngerokok udah"

Adapun Narasumber 1 menjadi memiliki sikap yang berbeda sebagai perokok aktif dalam memperhatikan lingkungan sekitarnya. Ia lebih memperhatikan lingkungan sekitar saat merokok. Seperti menjauh dari anak-anak atau orang lain, mencari tempat yang jauh dari orang-orang. Dalam hal ini Narasumber 1 tampaknya tidak bermaksud untuk mendapat penghargaan dari sekitar, namun menjadi suatu representasi menerima pesan yang disampaikan tentang bahaya merokok.

Abed (Narasumber 1): "Iya itu.. Itu bisa buat saya sadar saya perokok udah ketika saya yang lain kecil saya lagi makan nih di warung nasi padang atau mana misalnya orang lain itu saya liat ada anak kecil segala macem saya menjauh, karena kan perokok pasif berbahaya juga..

"Nah itu cuman buat saya sadar oh biar aja lah saya yang sakit orang lain jangan itu membuat saya apa.. Menjauh aja.. Misalnya saya ke taman agak jauh dari orang-orang yang anti rokok itu aja gitu.."

Di dalam temuan Penelitian ini, Peneliti mendapat temuan menarik dari hasil wawancara mendalam dengan 4 orang Narasumber terkait strategi penyampaian yang dilakukan oleh pembuat iklan. Meskipun zaman dan tekonologi sudah canggih seperti saat ini, Narasumber 1 berpendapat bahwa tidak semua masyarakat memiliki akun sosial media. Akan lebih baik apabila pesan yang disampaikan melalui media yang digunakan oleh seluruh kalangan masyarakat misalnya penayangan iklan layanan masyarakat lewat Televisi.

Abed (Narasumber 1): "Kemudian iklan itu ga.. jarang saya liat di televisi.. Nah hmm gini ya kaya dulu di jaman kita ada nih iklan layanan masyarakat kaya dulu awalawal kita pemilu kan ada kalo pemilu tiap hari ada di TV iklannya.. Hmm iklanan layanan msayarakat hmm akan merokok itu apa.. Hmm jarang.. Jarang sih di televisi jarang saya liat kan.. Jadi dia ini bagaimana kan itu tujuannya ke masyarakat ya bagaimana pesan itu sampai kalo misalnya melalui youtube atau melalui sosmed.. Emang semua masyarakat merokok punya media sosial? Iya kan jadi kalo pesannya pesan yang dibikin 
pemerintah itu pengen nyampe ke semua ya.. Gunain aja dimana masyarakat paling. Dimana masyarakat paling banyak bisa ngeliat iklan itu gitu iya kan.."

"Kalo misalnya di TV tiap acara pagi-pagi misalnya, setiap acara TV tuh selalu ada iklannya tampil disitu.. Selalu ada iklannya tampil sehingga sampe ke masyarakat yang lebih banyak.. Jadi sama kaya apa nih.. Kaya apa.. Kaya apa.. Kaya pandemi sekarangkan semua.. Semua memberitakan bahaya ini pandemi kan akhirnya kan hmm masyarakat sadar oh berbahaya nih kalo gua keluar rumah nah akhirnya masyarakat sadar.. Nah itu.. Pesan itu harus sampe ke masyarakat bahaya rokok itu seperti apa gitu.. Dan masyarakat harus melihat itu gitu, dimana mereka bisa melihat itu secara hmm gratis gitu kan.. Secara apa.. Pokoknya masyarakat harus melihat itu deh, iklannya bagus cuma kalo masyarakat ga melihat itu kan percuma gitu.",

\section{KESIMPULAN}

Berdasarkan analisis yang sudah dipaparkan di atas mengenai Iklan Layanan Masyarakat, efektivitas penerimaan pesan persuasif berhenti merokok dengan hashtags \#SuaraTanpaRokok pada kanal youtube Vital Strategies Indonesia adalah tergantung kepada Penerima pesan. Apakah pesan itu diterima atau tidak. Dalam Penelitian ini dapat disimpulkan bahwa pada dasarnya, isi atau konten Iklan Layanan Masyarakat yang dilakukan oleh Kemenkes sudah informatif dan jelas karena informan yang adalah perokok aktif dari penelitian ini, mengubah cara pandangnya saat sedang merokok di tengah banyak orang ia akan mencoba menghindari khalayak. Namun tidak menghentikannya untuk merokok, dalam artian pesan ILM tersebut tidak mempengaruhi motivasi diri atau niat yang berkaitan dengan berhenti merokok. Berdasarkan gagasan dari penelitian ini, maka dapat dilihat bahwa iklan layanan anti merokok tidak serta merta membuat perokok aktif di dalam penelitian ini berhenti merokok, namun lebih bertanggung jawab dan sadar atas kebiasaan merokoknya, artikel ini menjadi penting untuk diadvokasikan kepada pembuat iklan layanan masyarakat untuk dapat mempertimbangkan jalur sentral dalam model penerimaan elaborasi atau elaboration likelihood model agar semakin banyak masyarakat yang berhenti merokok berkat Iklan Layanan Masyarakat. 


\section{DAFTAR PUSTAKA}

Briandana, Rizki, Tirta Lestari, and Rustono Marta. 2020. "Efektivitas Iklan Melalui Sms Blast Terhadap Keputusan Pembelian Konsumen”. Jurnal Lensa Mutiara Komunikasi $4 \quad$ (2), 98-112. http://ejournal.sarimutiara.ac.id/index.php/JLMI/article/view/1454.

Cho, K. W., Lee, J., Ryu, J. hye, \& Kim, S. J. 2017. "Effects of anti-smoking public service announcements on the attitudes of Korean college students toward smoking". Osong Public Health and Research Perspectives. https://doi.org/10.24171/j.phrp.2017.8.6.07

Daiton, M., \& Zelley, E. 2004. "Applying Communication Theory for Professional Life : A Practical Introduction". Applying communication theory for professional life.

Flynn, B. S., Worden, J. K., Bunn, J. Y., Connolly, S. W., \& Dorwaldt, A. L. 2011. "Evaluation of smoking prevention television messages based on the elaboration likelihood model". Health Education Research. https://doi.org/10.1093/her/cyr082

Lincoln, Y. S., \& Guba, E. G. 1985. "Naturalistic Inquiry". Transplantation.

Long, P., \& Wall, T. 2012. Media Studies: Text, Production, Context. Routledge.

Nkunya, T., Periyayya, T., \& Sinappan, S. 2017. "Enhancing the effectiveness of tobacco package warning labels: An elaboration likelihood perspective". SEARCH (Malaysia).

Petty, R. E., \& Cacioppo, J. T. 1986. "The elaboration likelihood model of persuasion". Advances in Experimental Social Psychology. https://doi.org/10.1016/S00652601(08)60214-2

Schmidt, A. M., Ranney, L. M., Pepper, J. K., \& Goldstein, A. O. 2015. "Source Credibility in Tobacco Control Messaging. Tobacco Regulatory Science". https://doi.org/10.18001/trs.2.1.3

Stephen W. Littlejohn, Foss, K. A., \& Oetzel, J. G. 2012. "Theories Of Human Communication Eleventh Edition". Waveland Press, Inc. https://doi.org/10.1017/CBO9781107415324.004

Sugianto, Arifin, and Antonius Sembiring. 2019. "Kampanye Public Relations Dalam Membentuk Sikap Positif Khalayak”. Jurnal Lensa Mutiara Komunikasi 2 (1), 45-60. http://ejournal.sarimutiara.ac.id/index.php/JLMI/article/view/560.

Suatan, Alexandra, and Irwansyah Irwansyah. 2021. "Studi Review Sistematis: Aplikasi Teori Disonansi Kognitif Dan Upaya Reduksinya Pada Perokok Remaja". JURNAL $\begin{array}{lllll}\text { LENSA } & \text { MUTIARA } & \text { KOMUNIKASI } & 5 & (1),\end{array}$ https://doi.org/10.51544/jlmk.v5i1.1556.

Terskikh, M. V. 2016. "Public Service Announcements and their Influence Upon System of Values of Children (Research of Concept of "Family" Formation)". Procedia - Social and Behavioral Sciences. https://doi.org/10.1016/j.sbspro.2016.10.168. 